\title{
ArTicle
}

\section{The Butcher, the Baker, And the Candlestick Maker: John Dewey's Philosophy of Art EXPERIENCE SAVIng Twenty-First-Century Art EdUCATION From Limbo}

\author{
Anne G. Jones and Michael T. Risku
}

\section{ABSTRACT}

To satisfy the demands of society, the scholar-practitioner in today's complex world of education must juggle various factors that are related to one another: practice, poiesis, or the creative act, culture, knowledge, and learning. These demands include adherence to education, law, politics, economics, ethics, equity, and social dynamics. The scholar-practitioner in the field of visual arts education also has the duty to validate the arts as a viable and necessary component of education, and this is done through examples of scholarly practice. The scholar-practitioner as leader should be grounded in the works of John Dewey, including Art as Experience, Experience and Nature, and Experience and Education. With Dewey's conception of the scholar- practitioner as a public intellectual engaged in educational practice to transform society, there is the fostering of a learning environment for educators, students, and community that is balanced with the basic needs of daily living. This article provides a closer look at the history of visual arts education, a review of Dewey's philosophy of art experience, and an exploration of why there may be a need for Dewey's philosophy within $\mathrm{K}-12$ art education in the United States.

\section{Visual Arts Education}

Researchers in the areas of prehistoric art, anthropology of art, psychology, philosophy, feminist art theory, histories of visual arts education, and the emerging field of neuroaesthetics have created new interest within education in the writings of John Dewey related to art and experiential learning as found in Art as Experience and Experience and Nature. Thus, another look at Dewey's life experience and his philosophy of experiential art may bring renewed support for visual arts education in the twenty-first century. Dewey has influenced the public education 
system through his philosophy of experience and his less well-known theory of aesthetics. The definition that Dewey provided for education centers on the process of growth, and this growth occurs with intellectual initiative, independence of observation, judicious intervention, foresight of consequences, and ingenuity of adaptation. This experiential process of learning incorporates thought and reason applied to an activity creating passion for ownership of the process. Knowing does not exist isolated from action, and participation is the connecting element between the psychological and social factors within the process of learning. Dewey strongly rejected the idea of passivity on the part of the learner. Finality is never an element of learning, and the education process is seen as interrelated, ongoing, and changing. The visual arts experience enables learning, and this experience of understanding and knowing is the process that shapes lives. Dewey stated that it is by way of communication that art becomes the incomparable organ of instruction, but the way is so remote from that usually associated with the idea of education that we are repelled by any suggestion of teaching and learning in connection with art.

Visual arts education as practice draws on many fields and theories within the arts, such as art history, art criticism, studio art, aesthetic theory, philosophy, and education. The two main areas in the theory of the visual arts are those dealing with cognitive and expressive ideals. There are other fields and movements that overlap and shape contemporary art education as well, such as those involving gender, social, political, and ethnic issues. Visual arts education today is a result of what ideals have been accepted or rejected by the political/education system. At any given time in the history of the United States one can see the relationship between the needs of society and the values of society. The direction of education responds to these needs and values with the focus of art education functioning as a component of education. Dewey came to view the visual arts experience as an intrinsic part of human life, culture, and society. He was not a practicing visual artist. However, with investigation of Dewey's philosophy of art experience as essential to both life experience and his subsequent philosophy of aesthetic experience, this interpretation may reveal evidence that Dewey's philosophy is within the heart of the global culture. A further study and evaluation of the visual arts experience within education may validate the importance of the visual arts as a vehicle for knowledge. Dewey constructed a theory of visual arts process away from the museum ideal and toward a conception of art as a social function.

\section{Dewey's Philosophy of Art}

Biographers of Dewey, including Jay Martin, Sidney Hook, George Dykhuizen, Jane Dewey, and Mary Dearborn, have allowed us a glimpse into Dewey's life experience. This life experience includes his involvement with the world community, his family and friends, and his personal philosophic focus and passions during his 
historical era. Dewey's philosophic focus bore different titles as he grew and reconstructed his principles through this life experience. The field of education and social and economic culture retain their vitality because Dewey negated finality. His philosophy of experience and growth allowed for the use of many descriptors for his philosophic theory: neo-Hegelianism, pragmatism, instrumentalism, experimentalism, operationalism, radical empiricism, idealistic empiricism, naturalistic empiricism, and transactionalism. Dewey believed that the visual arts transcend time, celebrating with intensity the moments in which the past reinforces the present. Actuality and possibility, old and new, individual and universal are integrated in the experience. The visual arts process for Dewey was more than art production; it was a necessary human activity.

The complex world of education today is made of the many relationships between practice, poiesis (the creative act), culture, knowledge, and learning. The scholar-practitioner must work with these relationships to satisfy the demands of society at large. These demands include adherence to education, law, politics, economics, ethics, equity, and social dynamics. The scholar-practitioner within the field of visual arts education also has the duty to validate the arts as a viable and necessary component of education. This is accomplished through examples of scholarly practice. The scholar-practitioner as a leader within the field of art education should be grounded in the works of Dewey. Dewey's conception of the scholar-practitioner is that of a public intellectual engaged in educational practice to transform society through the fostering of a learning environment for educators, students, and community that is balanced with the basic needs of daily living. The scholar-practitioner as visual arts educator is self-reflective and aware of the personal lenses affecting practice.

\section{A Brief History of Visual Arts Education}

Dewey's legacy in visual art as experience is evident in recent research outside of the art education discipline. Elliot W. Eisner, art educator in the Chicago public schools, the Laboratory School of the University of Chicago, and Stanford University, has long concurred with the need for research to support how the arts contribute to the growth of mind. He has continued to dispel the idea that creating art is somehow an intellectually undemanding and emotive rather than reflective activity. Eisner argues that many of the most complex and subtle forms of thinking take place when students have an opportunity either to work meaningfully on the creation of images or to scrutinize them appreciatively. Anthropologist Ellen Dissanayake began in the late 1980s to present her scholarly research on the production of the visual arts as critical to humankind. She described the visual arts as a universal characteristic or behavior of humankind. Dissanayake stated, "I emphasize the behavior or activity rather than as other theorists have done, the results: the things and activities themselves as works of art." ${ }^{\text {' }}$ She further believed 
that the species-centric view of art recognized and proclaimed as valid and intrinsic the association between what humans have always found to be important and creations called the "arts." The arts have always grasped, manifested, and reinforced what humans have found as important. That the arts in postmodern society do not perform these functions, at least to the extent that they did in premodern societies, is not because of some deficiency or insubstantiality of an abstract concept, but because the art makers inhabit a world unprecedented in human history. This is a world in which these abiding concerns are artificially disguised, denied, trivialized, ignored, or banished. ${ }^{2}$

Dewey, from the beginning of the Laboratory School, was an advocate for progressive reform, believing that schools should be social centers where groups of children explored subject matter selected with their interests, the local community needs, and the modern industrial society needs in mind. ${ }^{3}$ Contrary to Plato's idealism, where art is an imitation of nature, Dewey defined the aesthetic experience as an enriching encounter between an individual and an event that celebrates the life of a civilization. This art experience allowed for ongoing learning through the art process as a way of life; it was interactive and occurred in nature as reflective of both the person and socially constructed reality. This process was a validation of the learning experience. The demystifying of the experience, previously allowed only to a few, opened the door for a way to approach an art education experience that communicated to all. This lived experience, according to Dewey, was the fulfillment of an organism in its struggles and achievements in a world of things: "It was art in germ."' Dewey's conception of education as a force for social reconstruction dominated progressive reform efforts before World War I. Further, the romantic ideal of self-expression, grounded in Freudian psychoanalysis and an expressionistic aesthetic derived from avant-garde art, contributed more to the child-centered pedagogy of progressive schools. ${ }^{5}$ The progressive era also saw many women become prominent in art education.

The publication of Victor Lowenfeld's Creative and Mental Growth in 1947 helped initiate children's art education grounded in psychoanalytic constructs. Mental health and physical and emotional growth were emphasized as the aims of art education. Lowenfeld saw the adult social environment as a corrupting influence and urged teachers to shelter children from its repressive effects. His child-centered approach became the norm in art education as the field of education moved "back to basics." Insulation from the world outside of the school is the antithesis of Dewey's theory of visual arts experience. Child study researchers through most of the twentieth century assumed that children's artistic development followed a linear path, progressing from nonobjective scribbles to controlled representation. Art educators and psychologists today recognize that children's art-making, like adult artistry, occurs within a social context. Beliefs about the nature of art affect how adults interpreted children's images and their purpose for 
art-making. Contemporary artists focus on the functions of children's art-making, children's attempts to convey meaning, and how sociocultural values encourage certain genres. ${ }^{6}$ Art education textbooks from 1945 through 1960 showed some loyalty to the ideals of progressive education and the goals of the life adjustment movement. ${ }^{7}$ In the years following World War II, many U.S. citizens were given the means to start or continue an education through the G.I. Bill. Vincent Lanier, art educator and recipient of educational opportunities from the G.I. Bill, has stated, "The teaching of art, while it was by no means a high priority among the concerns of public education, was an accepted member of the curricular family. Best of all we knew precisely what we were about; our role in the school was to fashion better people: more creative, more perceptive, more humane, better adjusted, and mentally adept-all of this in their general behavior."

Lowenfeld's theory of art education was the central focus of art educators of this time. In reference to Lowenfeld and art education curriculum of that time, Lanier asserted that it seemed as if one was released from the obligation to think. Thus Lanier, through observation of his students and their artwork, decided to shun the disapproval of his peers and looked for alternatives to Lowenfeld for children's art education. Lanier, Manuel Barkan, and Harry Broudy, art educators at the time, suggested that not only studio expression, but art history, art criticism, and aesthetics should be included within the art curriculum. Manuel Barkan challenged Lowenfeld's ideas, drawing heavily on Dewey's theory of art experience in the social environment where the child interacts with others, and through these encounters, grows into a social being. Generally regarded as one of the leaders in reconceptualizing art education, Barkan was born in New York City in 1913 and graduated from New College at Teachers College. The experimental program of New College was established to counter the effects of the Great Depression and was grounded in the ideas of Dewey; this program put students at the center of education while preparing teachers who would recognize and respond to the impact of existing economic and social conditions. ${ }^{9}$ Barkan chaired the art department at Ohio State University and published his dissertation in 1951 as A Foundation for Art Education. Barkan developed curriculum guidelines for aesthetic education, which provided an intellectual foundation for the Aesthetic Education Program at the Central Midwestern Regional Educational Laboratory. In the 1950s there was an analytic revolution in English-speaking aesthetics and Dewey's work was caught in this condemnation, with his theories of expression and creativity as particular targets of analytic attack. He was also condemned for using expression as a defining characteristic of art, although his own distinctive theory of expression was often ignored in the process. ${ }^{10}$ Dewey's aesthetic theory became virtually unknown to many art educators with the dominance of Lowenfeld's isolationist theories of art education in the 1950s and 1960s. In both higher education and K-12 education, Lowenfeld's theories dominated art education. 
In 1957, with the launch of Sputnik by the Soviet Union, Americans were told that the schools had failed to provide enough good scientists to compete with the nation's enemies. Efforts were made to change the curriculum in the schools through federal intervention, and education in this part of the twentieth century became a void in terms of the visual arts. For more than two decades after Sputnik, national defense and economic considerations could effectively cancel out every humanistic argument for the arts. ${ }^{11}$ There were two main reactions in the art education community: (1) new stress on the importance of art for its ability to enable creative problem solving, and (2) an emphasis on art as a structuralized discipline unto itself. ${ }^{12}$ After Dewey's death in 1952, McCarthyism sent messages of fear and self-censorship throughout academia, with funding for research interests supported by a combination of government and business interests. ${ }^{13}$ Hundreds of art teachers lost their jobs in states like New York and California, and many of those who remained were compelled to sign loyalty oaths. ${ }^{14}$ The arts, as well as art education, had adopted a safer stance in the back row of education with Lowenfeld's linear theory of art education, discipline-based art education, and the lack of activism. During the 1950s and 1960s much of Dewey's theory of art experience had become virtually unknown to many art educators because of the dominance of Lowenfeld's isolationist theories of art education. Efforts were made to change the curriculum in the schools through federal intervention, and art education was relegated to the bottom of the list of subject importance. The back-to-basics movement in the 1960s resulted in a reevaluation of K-12 art education and a shift to core subject-centered art education. The duality of the arts and the sciences grew in opposition to Dewey's anti-Cartesian philosophy. The influx of analytical philosophers, German art educators, the changing political world due to McCarthyism, and the launch of Sputnik changed the face and focus of education and the status of art in the United States in the latter half of the twentieth century. An all-encompassing history of art education was, for the most part, lost to the art student in higher education. Intensive examination of theoretical and historical issues, with the teaching of aesthetics, art history, and the sociology of art, were not present in preparation classes for the visual arts teacher. The art curriculum was not a product of a specific situation, but of governmental controlling agencies; and in the first decade of the twenty-first century much of Dewey's philosophy of art experience and progressive thought was underutilized in K-12 education. The focus of K-12 art education turned toward the Goals 2000: Educate America Act. The National Visual Arts Standards (NVAS), as part of the federal law, Goals 2000: Educate America Act, are the legal mandate for art educators in the twentyfirst century. They are standards and guidelines for the states, not the curriculum. Given the status of art education in the United States, the central question is, How does the visual arts educator work within the guidelines of the NVAS and maintain a personal philosophical validation for his or her art? 


\section{An Exploration of Why There May Be a Need for Dewey's Philosophy of Art Experience in EducAtion}

Justification for the inclusion of the fine arts in Goals 2000 was based on the idea that by providing standards and demonstrating accountability, and therefore the knowledge and skills that all students must acquire in the fine arts, the fine arts could be considered a core subject in K-12 education and not mere "fluff." The latter attitude about the arts was developed in the second half of the twentieth century. Here, the art educator became part of the accountability system through standards defining content and assessing outcomes in ways embraced in other subject areas; through the standards-based accountability system the art educator could demonstrate proof of what had been taught and learned. However, student achievement was more difficult to demonstrate within a system valuing verbal over visual expression. Art educators thus had to develop demonstrations of student achievement through student portfolios, oral and written responses, and a carefully designed grading system. The standards were intended to provide a clear statement of the mission of art educators as well as a consensual voice when speaking to governing and policymaking bodies. The requirement of fine arts inclusion in K-12 education was written into federal law with the passage of Goals 2000. Initially, the fine arts were not included as core subjects in Goals 2000. Early in 1991 and into 1992, the National Art Education Association (NAEA), with the consortium of National Arts Education Associations for music, dance, and theater, the National Endowment for the Arts, and the National Endowment for the Humanities, approached the U.S. Department of Education for a grant to study what children know and purportedly need to know in the arts. These groups responded by developing national "voluntary" fine arts standards to become part of the Goals 2000 initiative. The arts were identified as core subjects of equal importance in education as traditional academic subjects. Supporters of the initiative have advanced these standards as a remedy for the lack of standardized expectations and evaluation instruments within K-12 education. Notably, Dewey, in Art as Experience, wrote about standards in relation to the visual arts and the art critic. He described the subtle difference between the terms "standards" and "criteria." Dewey stated that the term "standards" denoted a kind of linear measurement, an impossible notion for the fine arts. ${ }^{15}$ Eisner later argued that Dewey's observations on standards versus criteria offered a far more sophisticated conception of the way aims can be formulated and performance evaluated within the visual arts. The perception of the visual arts as allowing for standardization is not only an educational issue, but also a societal issue; Eisner stated that teachers need to focus on how students must think in order to get the results they acquired and what they learned as a result. To do this, they must penetrate below the surface features of their activity to get at what lies beneath it.

Life's ordinary experiences become extraordinary through Dewey's "texts of experience." His use of everyday life experience as a basis for conceptualizing 
art making, along with the modern anthropologists use of art as denoting socially shared significances, challenge the data-driven education world to rethink the significance of the arts in modern American democratic culture. Dewey's philosophy of art experience liberates us from narrowly conceived and controlled definitions of art and challenges standard conventions concerning what is important for humanity while helping learners understand the nature and functioning of social, biological, and political systems.

Art educators can transcend the restraints of the twenty-first-century K-12 education system in the United States, as formulated within Goals 2000, by developing a personal philosophy of visual art experience based on Dewey's philosophy of experience. Goals 2000 is a federal initiative, and this seems to imply permanence within the twenty-first-century education system. Dewey's Art as Experience, however, is an important philosophical foundation for the development of a personal philosophy of visual arts education that addresses and complements the National Visual Arts Standards. In the 1990s, Dewey's philosophy played a significant role in some of the ongoing dialogue on the arts and education. Feminist issues and concerns were seen as relevant within art education, and the history of art education in the United States included indigenous peoples. However, this increased perspective remained mostly within higher education. The addition of the National Visual Arts Standards in K-12 education and society at large as federal policy has given authenticity to the field as a validation for art in the K-12 curriculum. However, without a stated philosophical foundation that is broadly understood, the standards do not speak to the nature of the arts as valuable for understanding what it is to be human. The notion of the arts as an integral part of everyday life is not found within the standards alone. There have been varied foci and descriptors as to what is/was art education. The standards are in place within Goals 2000; however, the need for a philosophical foundation, social context, and community-related curriculum for art educators within the K-12 education organization has been overlooked.

Dewey's Art as Experience may be important to K-12 art education as a philosophical foundation that adds value to and complements the National Visual Arts Standards, and in offering a way for art educators to develop and implement a personal philosophy of arts education in order to address these standards, in addition to liberating and enhancing the lived experience of the student and teacher. The National Visual Arts Standards will remain in existence for the foreseeable future. If Art as Experience is "taken seriously" and utilized as a philosophical foundation for the standards, "not only do art educators have much to gain [from reading Art as Experience and taking its lesson to heart]," writes Philip W. Jackson, "we all do."16 The degree to which Dewey's philosophy alters the potential for thinking about the visual arts by American artists and art educators has not been fully explored in the twenty-first century. Dewey's lived experience has arguably freed American artists 
and art educators from the ideals of Hegel and Croce by presenting the arts outside of the compartmentalization of skills and purpose.

\section{CONCLUSION}

Dewey would likely argue that modern technology is merely a tool of the artist; therefore, the twenty-first-century art educator must diligently reinforce handson experiences. This vital activity embeds the lived experience within the learning process, and this must be passed on to $\mathrm{K}-12$ art education practitioners in the twenty-first century. Unfortunately, the education world has largely succumbed to the ways and means of the business model. Leaders freely use the term "our business" to describe the purpose of teaching and learning. Teachers entering the field today are a product of this way of thinking, which perpetuates the paltry, destructive idea that children are mere data. The quantitative is now the benchmark for children's learning. The authors of this article wonder how Dewey would react if he were to observe a day in the life of an American student in the twenty-first century. From the prepackaged, carbohydrate-laden institutional meals to the technology that overrides the teaching of the basic skills of handwriting and drawing, the student has been pushed away from Dewey's conjoint experience of life and culture as a vehicle for learning. The enduring history of art education in the United States as an integral part of the school curriculum is unknown to most modern educators and artists. The fine arts have been relegated to the bottom of the ladder of importance because they typically do not appear on state-mandated tests. The value of and respect for the trained artist has largely disappeared, as volunteers with little training facilitate the only art experience available in too many elementary schools. For example, one of us has observed that during "free time" in the elementary classroom, drawing is not allowed. As a reaction to this, the children are forced to draw clandestinely on scraps of paper hidden in their desks. But Dewey reminds us that children are not data, and life is not a prepackaged series of events. Lower socioeconomic schools, in particular, have communities that depend on the schools to deliver valuable educational experiences for their children. There is a tragic irony here in that the families living at or below the poverty level, which often provide few books and little to no experiences with the arts and culture, do in many cases provide television, computer games, and processed snacks to eat while engaged with this technology. And the schools provide little more for the child with regard to the arts and cultural awareness.

The process of learning as conceptualized by Dewey is absent in American society today, and in this product-oriented education system, students do not have the opportunity to internalize the importance of the process of learning in relation to the product; therefore, students do not experience the value of learning and the value of the role that the arts play as a vehicle in this experience. Twenty-first-century artists share part of the blame in allowing the loss within society of knowledge of 
the strong foundation of academics and technique involved within the art-making process. Through public relations efforts of many modernists and literary-based postmodernists, much of the work of the visual artist has been separated from culture and society. The story of the art process and the value of this process must be advocated by the artist- as-practitioner and educator, using his or her personal philosophy and engaging in dialogue about the value of Dewey's philosophy of the art experience. Political and policymaking bodies have and will continue to make decisions for young learners that will further disengage them from the value of and passion for art and culture and the meaning of what it is to be human; the adults who endure this experience will suffer a void that can never be filled. American society will arrive at a point where there will be no reclamation of the socially shared significances of the arts, because society as a whole will no longer value what it does not know.

\section{Notes}

1. Ellen Dissanayake, What Is Art For? (Seattle: University of Washington Press, 1988), 71.

2. Ellen Dissanayake, Art and Intimacy (Seattle: University of Washington Press, 2000), 200-3.

3. John Dewey, Human Nature and Conduct: An Introduction to Social Psychology (New York, NY: Cosimo Classics, 2007), 65.

4. John Dewey, Art as Experience (New York, NY: Perigee Books, 2005), 285-99.

5. Mary Ann Stankiewicz, Roots of Art Education Practice (Worcester, MA: Davis, 2001), 33.

6. Ibid., 39 .

7. Arthur D. Efland, A History of Art Education: Intellectual and Social Currents in Teaching the Visual Arts (New York, NY: Teachers College Press, 1990), 228, 236.

8. Vincent Lanier, The World of Art Education According to Lanier (Reston, VA: National Art Education Association Press, 1991), 25.

9. Stankiewicz, Roots of Art Education Practice, 114.

10. Stanford Encyclopedia of Philosophy, s.v. "Dewey's Aesthetics," http://plato.stanford .edu/entries/dewey-aesthetics/

11. Peter Smith, The History of American Art Education: Learning about Art in American Schools (Westport, CT: Greenwood Press, 1996), 206-7.

12. Efland, A History of Art Education, 237.

13. David A. Price, Threatening Anthropology: McCarthyism and the FBI's Surveillance of Activist Anthropologists (Durham, NC: Duke University Press, 2004), 346.

14. John Demos, The Enemy Within: 2000 Years of Witch-Hunting in the Western World (New York, NY: Viking Penguin, 2008), 270.

15. Dewey, Art as Experience, 320.

16. Jim Garrison, ed., The New Scholarship on Dewey (Dordrecht, Netherlands: Kluwer, 1995), 25.

\section{BiBLIOGRAPHY}

Boydston, Jo Ann, ed. The Later Works of John Dewey: Volume 10: 1934. Carbondale: Southern Illinois University Press, 2008. 
Demos, John. The Enemy Within: 2000 Years of Witch-Hunting in the Western World. New York, NY: Viking Penguin, 2008.

Dewey, John. Art as Experience, 1st ed. New York, NY: Minton Balch, 1934.

-_- Art as Experience. New York, NY: Perigee Books, 2005.

-_- Democracy and Education. Middlesex: Echo Library, 2007.

-_- Experience and Education. New York, NY: Touchstone, 1997.

-_- Experience and Nature. New York, NY: Dover, 1958.

- - - Human Nature and Conduct: An Introduction to Social Psychology. New York, NY: Cosimo Classics, 2007.

Dissanayake, Ellen. Art and Intimacy: How the Arts Began. Seattle: University of Washington Press, 2000.

_-_. What Is Art For? Seattle: University of Washington Press, 1988.

Drepperd, Carl W. Pioneer America: Its First Three Centuries. Garden City, NY: Doubleday, 1949.

Efland, Arthur D. A History of Art Education: Intellectual and Social Currents in Teaching the Visual Arts. New York, NY: Teachers College Press, 1990.

Eisner, Elliot W. The Arts and Creation of Mind. New Haven and London: Yale University Press, 2002.

Garrison, Jim, ed. The New Scholarship on Dewey. Dordrecht, Netherlands: Kluwer, 1995.

Lanier, Vincent. The World of Art Education According to Lanier. Reston, VA: National Art Education Association Press, 1991.

Macdonald, Stuart. The History and Philosophy of Art Education. Cambridge, MA: Lutterworth Press, 1970.

Masten, April. Art Work: Women Artists and Democracy in Mid-Nineteenth-Century New York. Philadelphia: University of Pennsylvania Press, 2008.

Price, David A. Threatening Anthropology: McCarthyism and the FBI's Surveillance of Activist Anthropologists. Durham, NC: Duke University Press, 2004.

Smith, Peter. The History of American Art Education: Learning about Art in American Schools. Westport, CT: Greenwood Press, 1996.

Stankiewicz, Mary Ann. Roots of Art Education Practice. Worcester, MA: Davis, 2001.

Tanner, Laurel N. Dewey's Laboratory School: Lessons for Today. New York and London: Teacher's College Press, 1997.

Anne G. Jones is a visual arts educator with the North East Independent School District. Email: anneejo@satx.rr.com.

Michael T. Risku is a professor of education in the Dreeben School of Education at the University of the Incarnate Word. Email: mrisku@satx.rr.com. 
